\title{
scripted
}

Volume 10, Issue 3, October 2013

\section{EDITORIAL: OUR DIGITAL FUTURES}

Judith Rauhofer, Daithí Mac Síthigh ${ }^{*}$

DOI: $10.2966 /$ scrip.100313.307

\section{(c)}

C Judith Rauhofer, Daithí Mac Síthigh 2013. This work is licensed under a Creative Commons Licence. Please click on the link to read the terms and conditions.

\footnotetext{
* University of Edinburgh.
} 
"Our digital futures: technologies without boundaries" was the theme of the $29^{\text {th }}$ annual conference of the British \& Irish Law, Education and Technology Association (BILETA) ${ }^{1}$ and some of the best papers of this event are brought together here in this special edition of SCRIPTed. The city of Liverpool was an ideal location to explore our digital futures in more detail, having in recent years risen like a Phoenix (or a Liver bird?) from the ashes of old industries to re-invent itself with the help of new technologies and a vibrant creative sector. The Mersey beat could still be heard whether students debated "the case of the sentient computer" or whether the use of Big Data to create "smart cities" got privacy advocates excited.

The conference was officially opened by Prof. Andrew Murray of the London School of Economics and Political Science (LSE) who used his keynote address to ask the still existential question of what cyberlaw (and cyberlawyers) can bring to the table of general academic discourse. Murray is an influential scholar of law and technology; his OUP textbook on Information Technology Law: the Law and Society (now in its $2^{\text {nd }}$ edition) will be known to many readers, and his critical engagement with the work of Lawrence Lessig and advocacy for 'dynamic' and 'symbiotic' approaches to regulation is also familiar. In his address, Murray took one of the more popular sports in the field of IT law or cyberlaw - defining and critiquing the field. His provocative observation was that cyberlaw scholars have turned to sources outside of law to justify the status of cyberlaw, rather than taking on difficult questions within the discipline of law. Of great interest to the audience was Murray's argument that we have not had the impact we should on public policy (inquiries, parliamentary committees, etc). The speech came at a time when UK academic institutions were finalising their 'impact case studies' for the Research Excellence Framework. Indeed, many of the articles in recent issues of SCRIPTed demonstrate that academic work on topics of social and economic importance is being carried out. What steps need to be taken to put this work at the heart of the lawmaking process?

The articles in this special issue cover a range of issues in intellectual property and information technology law (other work presented at the conference will appear in due course in the European Journal of Law and Technology ${ }^{2}$ and the International Review of Law, Computers \& Technology). As one of the first academic analysis of a much-discussed 2012 decision on the 'resale' of software and copyright law, Andrew Nicholson responds to the decision of the Court of Justice of the European Union in UsedSoft $v$ Oracle $^{3}$. He reflects on both the decision and the way in which it has been received by those in legal practice and in the IT industries. Nicholson reads the decision as verification of Prof. Chris Reed's theoretical approach to the 'equivalence' of online and offline, but argues that technological change may soon make equivalence less useful as offline alternatives are phased out and an approach to business models relying on access to, rather than ownership of digital content (of the "Spotify" or "Netflix" variety) may make a second-hand market for digital goods unsustainable.

\footnotetext{
${ }^{1}$ http://www.bileta.ac.uk.

2 http://ejlt.org.

${ }^{3}$ Case C-128/11.
} 
Copyright is also the starting point for two explorations of a different type of 'online' issue by Kim Barker and Yin Harn Lee. Barker's contribution draws upon the consideration of work by scholars of games and virtual worlds, and she argues that the end user license agreement (EULA) is being used for purposes well beyond what is appropriate for its origins or legal status. Like Murray's renewed riposte to Lessig and Nicholson's gloss on Reed's recent work, Barker argues that key theories need continuing scrutiny, especially in the light of the changing practices of providers and users. She also draws interesting links between debates in consumer law, contract law, and copyright.

Lee's focus is on fan communities. Although this has been the subject of a series of articles, a couple of influential books and regular conference panels in the US, the question of the status of 'fan fiction' and other creative work under UK copyright law has not been well explored. Lee considers both the US and UK legal frameworks, and her approach is informed by the consideration of norms and practices among fan communities. She commends a 'more open and participatory business model' to rightsholders and discusses the range of existing practices, stretching from hostility to enthusiastic encouragement.

Eleni Kosta writes on challenges to the Data Retention Directive in the domestic courts of Bulgaria, Romania, Germany, Cyprus, and the Czech Republic, as well as pending cases in other jurisdictions and the forthcoming decision of the Court of Justice in response to preliminary references from Irish and Austrian courts. She reviews how the various courts evaluate the Directive under human rights law, and incorporates the observations of European institutions and others. Kosta calls for greater clarity and looks ahead to the matters that the Court of Justice might consider, out of those highlighted (or not highlighted) in the wide range of national cases to date.

Perhaps the four articles here respond to Murray's challenge that cyberlawyers need to have something to say to the community of legal scholars and to lawmakers. To this end, our digital futures do not only depend on the development of new and exciting technologies 'without boundaries', but also on those with the skill to bridge both technology and the law in different jurisdictions and in that often undefinable 'cyber' space. The authors consider the rule of law, the balance between various interests and institutions, and the development of different doctrines, including across different legal systems. Crucially, they also address some of their recommendations to those holding political office. While much has been said (not all of it good) by Ministers and funders about the role of universities in having an impact on the wider world, one of the core duties of the scholar is to intervene in public debate. Given the criticisms that many have (understandably) levelled at judges and politicians for not understanding or properly appreciating the big issues in cyberlaw, we have the responsibility to explain and disseminate our research to them. As an open-access online journal, SCRIPTed supports the bringing of conference discussions into the truly public sphere. We are grateful to Prof. Murray for allowing his speech to be republished in this issue, and to the four authors for their work on topics of such relevance and interest. 